\title{
Н.И. Бубнова
}

\section{НОВАЯ ААМИНИСТРАЦИЯ США: ВОЕННО-ПОАИТИЧЕСКИЕ ВЫЗОВЫ}

Бубнова Наталия Игоревна - кандидат исторических наук, ведущий научный сотрудник НИ ИМЭМО РАН им. Е.М. Примакова.

Дональд Трамп в ходе избирательной кампании делал ставку на уход от глобализма и концентрации на внутреннем развитии страны с элементами изоляционизма. Он призывал ставить американские интересы во главу угла «Америка прежде всего», укреплять свою страну, не тратя сил на других. При этом Дональд Трамп, как впрочем и Барак Обама до него, обещал не навязывать волю США другим народам, уйти от роли мирового жандарма.

В ходе избирательной кампании Трамп неоднократно говорил о нацеленности на взаимодействие с Россией. В качестве главных задач своей военнополитической стратегии он видел не преодоление «российской угрозы», а борьбу с запрещенной в России группировкой «Исламское государство», противодействие «возвышающемуся» Китаю, обеспечение кибербезопасности, совершенствование эффективности работы Пентагона. Этим объясняются долгое время продержавшиеся в России симпатии к Трампу: надеялись, что с ним «будет легче», что в случае его победы можно будет, по крайней мере, начать российско-американские отношения с чистого листа.

\section{«Поладить с Россией?"}

Стремление Дональда Трампа к сотрудничеству с Россией - это намерение руководствоваться национальными интересами и рациональными соображениями, но с нацеленностью на совместные действия и положительный результат. Первые шаги его свидетельствовали о том, что он будет стремиться предпринимать усилия в данном направлении, как и обещал во время избирательной кампании. Он исключил Россию из списка главных угроз США. В дни после слушаний в Конгрессе по поводу хакерских атак, в которых обвиняли Россию, Трамп писал у себя в Твиттере: «Иметь хорошие 


\section{РОССИЯ И МИР В ХХІ ВЕКЕ}

отношения с Россией - это хорошо, а не плохо. Только “глупые” люди могут думать, что это плохо» ${ }^{1}$.

От редакции. Социальные сети используются в политике не первый год. Однако новый президент США перевернул представление о том, как политик должен применять этот инструмент - переворот этот произошел в Твиттере. По наследству от Обамы Трампу достался официальный аккаунт, но гораздо активнее он использует свой личный аккаунт, созданный в марте 2009 г., - задолго до появления президентских амбиций.

Лексика и синтаксис Трампа поражают специфической скудостью. Фирменный стиль Трампа - это, в частности, писать в коние Твитта короткое слово с восклицательным знаком, например «грустно!» или «плохо!» (см.: Мартынов К. Твиттер Трампа. Очень страшно! // Новая газета. - М., 2017.15.02. - С. 10.)

Однако, вопреки ожиданиям многих и в России, и в США, и после избрания, и уже вступив на пост президента, Дональд Трамп пока не сформулировал четко своей стратегии в отношении России. Среди выдвигавшихся объяснений этому наряду с «компроматологией» (утверждениями, что Трамп находится под влиянием Кремля, поскольку там на него имеется компрометирующее досье) и мнением, что новому президенту просто не хватает стратегического подхода, любопытной представляется точка зрения, высказанная известным гарвардским профессором Стивеном Уолтом: «...может быть, Трамп и некоторые из его советников (наиболее показателен Стивен Бэннон ${ }^{2}$ ) исходят из широкого рамочного представления о “столкновении цивилизаций” Хантингтона, что предопределяет и их неприятие мультикультурализма внутри страны, и определение друзей и врагов за рубежом. Исходя из этого культуралистского, расово окрашенного мировосприятия, иудейскохристианский (преимущественно белый) мир подвергается осаде со стороны “других" сил, в первую очередь мусульманских. И с этой точки зрения идеальными союзниками являются не либералы, проповедующие терпимость, этнокультурное разнообразие и открытое общество, а скорее жесткие почвенники-государственники, которые любят границы, “стены”, сильных лидеров, подавление или маргинализацию любого, кто является иным (включая, разумеется, атеистов и гомосексуалистов), кто опирается на вполне традиционный набор культурных ценностей» [13]. Это сопоставимо, например, с тем, как после Второй мировой войны Соединенные Штаты по всему миру сделали

1. Режим достуna: https://twitter.com/realDonaldTrump?ref_src=twsrc\%5Etfw

2. Стив Бэннон - бывщий ведущий ультраправого сайта, возглавлявщий на завершающем этапе избирательный итаб Трампа, поклонник Ленина и противник иммигрантов и гомосексуалистов, которого Дональд Трамп сделал главным советником по стратегическим вопросам и включил в Совет начиональной безопасности. 
ставку не на либеральные демократии, а на диктатуры, которые они считали более эффективными в противостоянии коммунистам и социалистам.

Первый телефонный разговор между Владимиром Путиным и новым американским президентом состоялся вскоре после его инаугурации. Хотя российская сторона старалась не завышать ожиданий от этого звонка, подчеркивая, что он будет «только протокольным», в действительности обсуждались многие значимые темы совместной повестки дня, было, в частности, согласовано сотрудничество в Сирии. Отметим, что остаются такие вопросы, как урегулирование украинского кризиса, прекращение Сирийского конфликта, реализация Иранского ядерного соглашения, преодоление тупика, связанного с северокорейской проблемой, возобновление процесса контроля над вооружениями $[1$, с. 19-60, 95-108, 125-141] и другие, - решение которых может значительно выиграть в случае российско-американского взаимодействия.

Важный для России вопрос о санкциях в ходе телефонного разговора не обсуждался. Проблема санкций находится за рамками данной статьи и в контексте рассматриваемой темы имеет значение лишь постольку, поскольку санкции препятствуют российско-американскому сотрудничеству в военной и военно-технической сферах и, в частности, осложняют осуществление совместных мер по противодействию терроризму. Подчеркнем, что хотя от Трампа ожидают хотя бы частичного снятия санкций (в Конгрессе предпринимают упреждающие меры против этого), однако, как полагают сотрудники ИНИОН Дмитрий Ефременко и Анастасия Понамарева, нельзя считать благоприятной ситуацию, когда сокращение санкционного бремени становится предметом политического «размена». Скорее, предпочтительным, с их точки зрения, является вариант эрозии режима санкций, условия для которой могут быть созданы в результате прогресса на других направлениях российско-американских отношений и попыток Европейского союза адаптироваться к быстро изменяющейся обстановке [5, с. 14].

\section{Eвропа: Мир небезусловный}

В период до и после американских президентских выборов продолжалось размещение элементов американской ПРО в Румынии и Польше. В январе 4 тыс. американских солдат были переброшены в Польшу, 2 тыс. единиц американской тяжелой боевой техники, включая танки, были передислоцированы в Польшу, страны Балтии, а также в Румынию, Венгрию, Болгарию, а затем вслед за танками в Европу начали переправляться вертолеты. Председатель сенатского Комитета по вооруженным силам республиканец Джон Маккейн выступил с инициативой разместить американские войска в странах Балтии на постоянной основе. Во время слушаний по поводу утверждения 
Джеймса Мэттиса на посту министра обороны, Маккейн, который в качестве председателя профильного комитета вел дебаты, многократно и настойчиво повторял вопрос, поддерживает ли последний эту его инициативу, и добилсятаки положительного ответа. Характерно, что слушания происходили на следующий день после начала переброски американских танков и других вооружений в Польшу.

В ходе предвыборной кампании Трамп заявлял, что НАТО устарело, высказываясь критически по поводу того, что НАТО не борется с терроризмом. Он выражал недоумение, почему Соединенные Штаты должны нести бремя защиты своих союзников по НАТО, если, несмотря на договоренность об обязательном выделении на военные нужды $2 \%$ от ВВП, лишь четыре страны, помимо самих США, выполняют свои обязательства по финансированию военных расходов.

Наряду с НАТО, Трамп подвергал сомнению и актуальность Евросоюза. Он приветствовал решение Великобритании о выходе из этой организации, подвергал резкой критике политику Ангелы Меркель по приему беженцев, приведшую к волне иммиграции в европейские страны и создавшую, по его словам, большие проблемы для будущей безопасности ${ }^{3}$.

Тем не менее распространяющиеся сейчас представления о том, что Дональд Трамп будет выстраивать только двусторонние отношения и это приведет к роспуску и ЕС, и НАТО, не соответствуют действительности. НАТО со счетов не списывается, о чем во время визита Терезы Мэй заявил сам Трамп, а его министр обороны подчеркнул, что данная организация имеет абсолютную ценность. Но Брексит, проблема беженцев, протесты против НАТО в государствах-новобранцах - Болгарии, Черногории, вновь вспыхнувшие противоречия между Сербией и Косовом и с этническими албанцами внутри Сербии, заявление нового президента Молдовы Игоря Додона о том, что подписанное его страной Соглашение об ассоциации с ЕС может быть пересмотрено в пользу решения о членстве в ЕАЭС - эти события создают новую ситуацию для Европы, и вопросы безопасности нуждаются в пересмотре. Возникают новые императивы для налаживания взаимодействия и поиска путей восстановления российско-европейского и российскоамериканского сотрудничества.

3. Режим достуna: http://www.bbc.com/news/world-us-canada-38632485 


\section{Украинский конфликт и российско-американские отношения: Без экзистенциальных противоречий?}

В ходе избирательной кампании Трамп делал заявления, что Украина вне поля интересов США и что ее проблемами должны заниматься европейские государства. Это фактически означало отказ от американской силовой политики в отношении этой страны, но, впрочем, не исключало перспектив американского влияния на позицию официального Киева. Трамп даже упоминал о возможности признания Соединенными Штатами присоединения Россией Крыма (что было дезавуировано в первые недели его президентства).

В Киеве во время американской избирательной кампании однозначно высказывались в пользу Хиллари Клинтон в качестве кандидата в президента, украинские олигархи делали пожертвования в фонд Клинтонов, - что после победы ее соперника, естественно, снижает шансы этой страны на получение американских преференций.

В отличие от Хиллари Клинтон, Дональд Трамп никогда не высказывался в поддержку поставок летальных вооружений правительству Порошенко - на чем настаивали большинство в Республиканской партии в Конгрессе: последний законодательный акт на сей счет был принят Палатой представителей не далее как 21 сентября 2016 г. под названием «Акт за стабильность и демократию для Украины». А в военном бюджете, прошедшем утверждение в Конгрессе в декабре 2016 г., 350 млн долл. отводится на «военную помощь» Украине.

Дональд Трамп неизбежно будет испытывать большое давление со стороны Конгресса, большинство в котором считают Россию виновной в событиях на Украине. 27 сенаторов обратились 8 декабря с письмом к Дональду Трампу с требованием ужесточить американскую позицию в отношении России в связи с Украиной. Во время слушаний в сенатском Комитете по вооруженным силам по поводу назначения Джеймса Мэттиса на пост министра обороны ни один из участников слушаний не оспаривал тезиса о «российской агрессии», а председатель комитета сенатор Джон Маккейн говорил о том, что Россия «сбила самолет над Украиной» [8]. Перед самой инаугурацией 11 января группа сенаторов от Республиканской и Демократической партий представила внесенный сенаторами обеих партий законопроект «Противодействие российским военным действиям 2017», предполагающий введение новых санкций за действия Москвы на Украине и в Сирии и предусматривающий выделение 100 млн долл. на борьбу с «российской пропагандой и распространением недостоверных сведений».

В конце января 2017 г. ситуация на востоке Украины вновь резко обострилась. Интенсифицировались обстрелы населенных пунктов, украинская армия продвинулась вперед в нейтральной зоне разграничения огня. 
Представитель Государственного департамента Марк Тоннер выступил с призывом о немедленном прекращении огня и полном допущении представителей ОБСЕ в зону конфликта. Однако в его заявлении - в отличие от сделанного за месяц до того представителем предыдущей администрации - вина за кровопролитие не возлагалась на «российско-сепаратистские силы» (появившийся недавно новый «термин»), а требование прекратить насилие было безличным, не было адресовано именно Москве. Примерно в те же дни, что и заявление Тоннера, была опубликована статья в New York Times, где происходящее на Украине было названо «гражданской войной», а не войной России против Украины. Раньше такое обозначение украинских событий появлялось разве что в альтернативных СМИ. Означает ли это «подвижку» в восприятии Украинского кризиса и бо́льшую готовность за океаном признавать наличие интересов восточных украинцев? Правда уже через несколько дней только что назначенная представитель США при ООН Никки Хейли в своем первом выступлении в новой должности осудила - хотя и с оговорками - «агрессию России» ${ }^{4}$, а пресс-секретарь Белого дома Шон Спайсер сказал на брифинге для журналистов, что «президент невероятно жестко вел себя с Россией ...и очень ясно дал понять, что ожидает от российского правительства деэскалации насилия на Украине и возвращения Крыма» ${ }^{5},-$ хотя он же подчеркнул при этом, что США стремятся наладить отношения с Россией.

В случае с обострением ситуации на Украине трудно точно установить, «кто первым начал». Однако очевидно, что обострение не выгодно российской стороне, но оно в интересах Порошенко, не способного обеспечить выполнение Минских соглашений. Как в сентябре 2016 г. писал Стивен Коэн (его позиция, впрочем, подвергалась резкой критике со стороны вашингтонского мейнстрима), Порошенко, кажется, думает, что его спасение - в возобновлении войны Киева против восставших территорий, что может вернуть ему поддержку Вашингтона, но может привести к полномасштабной войне с Россией [7].

Позитивным следует считать тот факт, что в ходе встречи Нормандской четверки в Берлине 19 октября 2016 г. участники встречи подтвердили свою приверженность Минским соглашениям и договорились о выработке «дорожной карты» с целью их поэтапной реализации. России следует снова и снова напоминать западным контрагентам об установленном этими соглашениями порядке действий: сначала прекращение боевых действий и принятие конституционных поправок об особом статусе регионов Луганской и Донецкой областей и закона о местных выборах, согласованных с предста-

4. Режим доступа: http://www.voanews.com/a/united-states-condemns-russian-aggression-eastern-ukraine/3704001.html

5. Режим достуna: https://www.youtube.com/watch? $v=w Z E 2 s N z r B 30$ 
вителями властей регионов Донецка и Луганска, и назначение самих этих выборов, а затем уже начало передачи украинской границы под контроль Киева. В связи с приходом новой американской администрации возможна активизация неформальных российско-американских контактов по вопросу об Украине. Многие эксперты считают оптимальным «замораживание» ситуации, очевидно, что замороженный конфликт лучше, чем военные действия, но урегулированный конфликт лучше, чем замороженный. Не исключено, что с администрацией Трампа получится также провести некую кодификацию обязательства не принимать Украину в НАТО, да и конфликт в Донбассе не позволяет киевскому руководству - в соответствии с уставом этой организации - рассчитывать на скорое вступление в Альянс.

\section{Борьба с терроризмом:}

Разные ипостаси разными глазами

В противоположность предыдущим администрациям, остерегавшимся обозначать религиозную окраску терроризма [2, с. 82-85], Дональд Трамп открыто говорит о радикальном исламизме и необходимости противодействия как терактам, так и порождающей их идеологии. В марте 2015 г. в интервью $C N N$ он сказал: «Ислам ненавидит нас» ${ }^{6}$, а после событий в Берлине, где грузовик въехал в толпу на рождественском базаре, убив 12 человек, Трамп разместил в Твиттере сообщение: «Это чисто религиозная угроза, обратившаяся реальностью. Такая ненависть. Когда Соединенные Штаты и другие страны дадут отпор?» ${ }^{7}$

Борьбу с терроризмом и распространением радикального ислама Трамп обещал сделать основным направлением своей внешней политики (хотя иногда в качестве главной угрозы называл не терроризм, а Китай).

Борьба с терроризмом, которую Дональд Трамп сравнивал с противодействием фашизму во время Второй мировой и коммунизму в период холодной войны, в соответствии с его представлениями должна включать:

- совместные действия с союзниками по НАТО и из числа Ближневосточных стран;

- взаимодействие с Россией;

- запрет на въезд в США мусульманам.

Свое заявление о намерении - в качестве контртеррористической меры запретить мусульманам въезд в страну, сделанное после нападений в Париже в 2015 г., Дональд Трамп в дальнейшем модифицировал, уже не настаивая на

6. Режим достуna: https://www.youtube.com/watch?v=C-Zj0tfZY6o

7. Режим достуna: https://twitter.com/realDonaldTrump/status/812408189492797442 


\section{РОССИЯ И МИР В ХХІ ВЕКЕ}

полном запрете, а предлагая закрыть доступ в США только для приезжающих из государств «с доказанной историей терроризма».

При этом Трамп не исключал, что для отпора радикальному исламизму может потребоваться использование вооруженной силы. В своей речи в августе 2016 г., где в наиболее полном виде было представлено его ви́дение проблемы борьбы с терроризмом, Дональд Трамп сказал: «Моя администрация будет активно развивать совместные действия и военные операции в рамках Коалиции, чтобы сокрушить и уничтожить ИГИЛ, укреплять международное сотрудничество в целях отрезать их каналы финансирования, осуществлять расширенный обмен разведывательной информацией, проводить кибервойну, чтобы предотвратить и прекратить их пропаганду и рекрутирование» ${ }^{8}$.

Эксперты отмечают, что формулирование конкретной стратегии администрации Трампа по борьбе с ИГ еще впереди, а провозглашаемые меры - за исключением взаимодействия с Россией и запрета на въезд мусульман из «проблемных стран» - уже активно использовались администрациями сначала Джорджа Буша-младшего, а затем Барака Обамы. «Новым старым» является высказанное Дональдом Трампом предложение вновь разрешить прекращенные при Бараке Обаме пытки подозреваемых в терроризме и открыть по большей части закрытые при предыдущей администрации секретные тюрьмы. Причем если во время избирательной кампании Дональд Трамп говорил, что «подтопление» заключенных (waterboarding) - это не пытка, то сейчас, прямо используя это слово, вопрошает: «Вы скажите, пытки эффективны или нет?» ${ }^{9}$ - вместо того, чтобы задаваться вопросом, впрочем уже давно решенным в цивилизованном мире, о допустимости таких методов и о том, куда катится мир и до чего он может докатиться, если пытки будут разрешены.

Что же касается взаимодействия между США и Россией в борьбе с терроризмом, то оно действительно могло бы сыграть значительную роль. Однако для налаживания контртеррористического сотрудничества необходимо будет - как минимум - снять санкции, наложенные против российских спецслужб и отменить и принятые администрацией Обамы решения о замораживании контактов между военными. Поскольку в деле борьбы с этой главной угрозой Трамп видит основное направление для сотрудничества с Россией, имеется потенциал позитивного двустороннего и многостороннего взаимодействия.

8. Режим достуna: https://www.donaldjtrump.com/policies/foreign-policy-and-defeating-isis

9. Режим достуna: http://www.nbcnews.com/news/world/donald-trump-s-commentstorture-provoke-harsh-reaction-abroad-n 712381 


\section{Сирия: Пространство вражљы и горизонты примирения}

Вмешательство России в Сирийский конфликт было вызвано, наряду с желанием предотвратить государственный коллапс в этой стране и захват Исламским государством власти, стремлением поправить отношения с Западом, испортившиеся после присоединения Россией Крыма и начала конфликта на Украине. России удалось добиться того, что западные страны, и в первую очередь США, вынуждены были вести с ней переговоры по сирийскому вопросу. Однако неоднократно объявлявшееся прекращение огня и намечавшееся было российско-американское сотрудничество в осуществлении военных операций каждый раз прерывалось вследствие трагических инцидентов или же провокаций. За 2016 г. отношение американского руководства к российской операции в Сирии менялось неоднократно: в течение весны от критических оценок до признания важности российских действий, особенно ясно артикулированного в связи с российским заявлением о выводе войск, и затем снова летом-осенью до ниспровергающих обвинений в связи с российскими бомбардировками Алеппо и призывов осудить Россию и Сирию за военные преступления [11].

Подписанное в конце 2016 г. соглашение между Россией, Турцией и Ираном об установлении перемирия в этой стране обозначило путь урегулирования вне и помимо российско-американского направления, хотя Соединенные Штаты и поддержали затем Резолюцию 2336 ООН, одобрившую его. Использование термина «перемирие», а не «прекращение огня», фигурировавшего в предыдущих российско-американских договоренностях, охват наряду с заключившими его странами и правительственными войсками всех вооруженных группировок, кроме ИГ и бывшей ан-Нусры, было призвано вывести процесс урегулирования на иной, более прочный, уровень.

В конце января в Астане состоялась Международная встреча по сирийскому урегулированию. Всем странам, так или иначе причастным к поискам путей урегулирования сирийского конфликта, включая Соединенные Штаты, было направлено приглашение принять участие в мероприятии. Однако американская сторона, которой не было предложено место одного из основных действующих лиц, предсказуемо ограничилась участием лишь на уровне своего посла в Казахстане.

Заключенное соглашение свидетельствует об изменении расстановки сил в регионе, обусловленной как успехами правительственных войск при поддержке российской авиации, так и изменением позиции турецкого руководства, переставшего делать упор на немедленной отставке президента Сирии Башара Асада. Произошедшая переориентация России от сотрудничества с США на сотрудничество с Турцией вместе с тем не означает отказа от 


\section{РОССИЯ И МИР В ХХІ ВЕКЕ}

взаимодействия с Вашингтоном, которое станет более реальным, если объявленное перемирие превратится из продекларированного в реальное, и продолжающиеся вооруженные столкновения пойдут на убыль.

«Было бы здорово, если бы мы поладили с Россией, потому что мы могли бы вместе бороться с ИГИЛ» ${ }^{10},-$ говорил в ходе избирательной кампании Дональд Трамп. По данным недавнего исследования Университета Мэриленда, $67 \%$ республиканцев и $53 \%$ демократов в США хотят, чтобы их страна сотрудничала с Россией в Сирии в борьбе против ИГИЛ. Дональд Трамп поддержал российскую операцию в Сирии, провозгласив: пусть русские разбомбят их ко всем чертям! Он называл ИГ главным злом, а администрацию Барака Обамы обвинял в том, что она «создала ИГИЛ» (в дальнейшем он пояснял, что она своими действиями в Ираке и Афганистане создала вакуум, способствовавший распространению влияния ИГ).

Российско-американское взаимодействие в Сирии - это, конечно, трудно, но не невозможно. Неправы эксперты, которые утверждают, что интересы двух стран противоположны. Хотя Дональд Трамп осуждал российские бомбардировки в Алеппо, он не исходит из априори негативного представления о российских действиях в Сирии и не говорит, как это делала его оппонент на выборах, об однозначной «поддержке суннитов»: которая безусловно вела бы к усилению межконфессиональной и межэтнической розни. И Россия, и США согласны обсуждать политический процесс в этой стране - без которого невозможно достичь урегулирования. Американскому руководству придется отказаться от требования немедленной отставки Башара Асада - подвижки в этом плане отмечались уже при Бараке Обаме - и поддержки тех группировок боевиков, которые не готовы будут сложить оружие. А российской стороне следует иметь в виду возможную перспективу ухода Асада в результате политического процесса и всеобщих выборов. Как сказал Владимир Путин, «мы глубоко убеждены, что ничего нельзя делать вопреки воле народа» ${ }^{11}$.

После первого телефонного разговора Путина с Трампом американской стороной, по сообщениям СМИ, российским военным были переданы - впервые! - карты с расположением сил ИГ, и российские бомбардировщики нанесли удар по группировке в районе города Эль-Баб сирийской провинции Алеппо.

Если удастся договориться с Соединенными Штатами, то есть большая вероятность восстановления мира в Сирии и улучшения ситуации в регионе в целом - при возросшем влиянии России. То, что в один день было совершеwarl

10. Режим достуna: http://edition.cnn.com/2016/10/12/politics/us-russia-tensions-cold-

11. Путин назвал бредом заявления об угрозе для Прибалтики со стороны России // TACC. - 2016. - 5 октября. Режим доступа: http://tass.ru/politika/3593653 
но убийство российского посла в Турции Андрея Карлова и террористический акт в Берлине - как и годом ранее взрыв российского самолета совпал по времени с трагическими событиями в Париже - снова высветило общность угрозы терроризма и необходимость совместных усилий по противодействию ему.

\section{Американцы в Ираке: \\ Уходя не уходят?}

Хотя утверждения Дональда Трампа о том, что он изначально был против вторжения в Ирак, не соответствуют действительности, но он на самом деле очень критично относится к положению дел в этом государстве. Потеряв 5 тыс. своих солдат и фактически навязав Ираку конституцию, Соединенные Штаты не добились желаемой стабилизации страны. Дональд Трамп заявляет, что «Иран все больше и больше захватывает Ирак, в то время как США потратили там 3 трлн долл.» ${ }^{12}$. Действительно, по различным оценкам, в настоящее время до $70 \%$ иракской территории контролируется Ираном. Кроме того, в Ираке действуют курдские группировки и образована курдская автономия.

«Ирак - слишком большой, чтобы позволить ему не состояться», - пишет сотрудник Вашингтонского института ближневосточной политики Майкл Найтс [9], призывая администрацию Трампа, в частности, продлить операцию «Непоколебимая решимость» и продолжить финансирование Фонда по обучению и вооружению Ирака, а также подготовить новый трехлетний план по поддержке Иракской армии и созданной США Иракской контртеррористической службы. Специальный представитель США Брет Макгарк выступает за «функционирующую федерализацию» Ирака, предполагающую разделение власти между различными этноконфессиональными группами и урегулирование вопроса о будущем статусе Иракского Курдистана [12]. Воплощение данной идеи позволит США окончательно «уйти» из страны, не сдавая при этом позиций в пользу Ирана.

\section{Иранская ядерная сделка: \\ ^омать ими строить?}

Трамп многократно критиковал Иран, называя его пособником терроризма. Вновь назначенный им министр обороны Джеймс Мэттис тоже говорил, что считает Иран основным спонсором терроризма в мире.

12. Режим доступа: http://nationalinterest.org/feature/how-trump-can-take-iranwithout-sparking-war-19460 


\section{РОССИЯ И МИР В ХХІ ВЕКЕ}

На протяжении всей избирательной кампании будущий президент США негативно отзывался об Иранской ядерной сделке и обещал в случае избрания отказаться от соглашения.

Однако американские эксперты отмечают, что данный документ реально приостановил ядерную программу Ирана и сделал его действия более предсказуемыми. Кроме того, Ирану уже переданы 100 млрд долл., и в том случае, если Соединенные Штаты выйдут из соглашения, велика вероятность, что он продолжит работу над ядерным оружием, располагая при этом большими финансовыми средствами [10].

Тем временем в Вашингтоне по-видимому происходят некие «подвижки» по отношению к Иранскому ядерному соглашению. В ходе телефонного разговора между Дональдом Трампом и королем Саудовской Аравии Салманом аль-Саудом в конце января стороны обозначили намерение «энергично» добиваться выполнения соглашения ${ }^{13}$, хотя и с оговоркой о необходимости противостоять «дестабилизирующим действиям [Ирана] в регионе».

31 января 2017 г. в Иране прошло испытание баллистической ракеты средней дальности. В США в связи с испытанием иранской баллистической ракеты ввели новые санкции, затрагивающие 35 человек, работающих по ракетной программе Ирана. Министр обороны Джеймс Мэттис пояснил при этом, что, хотя «плохое поведение Ирана не станут игнорировать», дополнительного размещения американских Вооруженных сил на Ближнем Востоке не будет. Очевидно, что в налаживании диалога США с Ираном значительную роль может играть Россия, рассматривающая последнего как важного партнера в регионе.

\section{Не все дороги ведут к миру \\ на Земме обетованной}

В последний месяц пребывания в Белом доме администрации Обамы американская сторона впервые воздержалась при голосовании в ООН по поводу резолюции о запрете на размещение израильских поселений на палестинских территориях. В Израиле выполнять резолюцию отказались и выразили надежду на сотрудничество с вновь избранным президентом и Конгрессом. Трамп, в свою очередь, назвал Израиль «самым близким союзником», выступил за перенос официальной столицы этой страны из Тель-Авива в Иерусалим - на чем настаивает израильское руководство - и пообещал добиться окончательного примирения Израиля с Палестиной.

13. Режим достуna: http://www.middleeasteye.net/news/trump-saudi-king-agree-rigorously-enforcing-iran-nuclear-deal-1176051151 
В качестве нового посла в Израиль назначен Дэвид Фридман, поддерживающий перенос израильской столицы и выступающий против «иллюзии» о возможности создания «двух государств», за легализацию и расширение строительства новых поселений на палестинской территории, за увеличение финансовой помощи Израилю и против признания руководителя Движения за национальное освобождение Палестины (ФАТХ) Махмуда Аббаса «законным лидером» государства Палестина. Характерным для Фридмана считают выступление, где он сравнил американских представителей еврейской общины, выступающих в пользу концепции «двух государств», с евреями во время Второй мировой войны работавшими на нацистов в концентрационных лагерях.

Сотрудник вашингтонской экспертно-аналитической организации Фонд защиты демократий Уолид Фарес, являвшийся советником Трампа по внешнеполитическим вопросам в период избирательной кампании, назвал назначение Фридмана «оскорбительным» для союзников США из числа арабских государств и «хоронящим» все надежды на достижение соглашения между израильтянами и палестинцами ${ }^{14}$.

«Слишком долго акценты в ООН были несправедливо смещены в пользу Палестинской автономии в ущерб интересам нашего союзника Израиля» ${ }^{15},-$ было сказано в заявлении американского представителя в ООН Никки Хейли. А во время визита премьер-министра Израиля Бенджамина Нетаньяху в Вашингтон в феврале 2017 г. Дональд Трамп - первый из американских президентов за последние два десятилетия - сказал, что «готов принять и “одно государство" и “два государства" - если и те и другие с этим согласятся»" т.е. фактически отказался от поддержки идеи создания независимой Палестины.

С приходом Трампа в Белый дом Тель-Авив связывает значительные надежды. Однако явные предпочтения нового американского президента в пользу Израиля затрудняют для Соединенных Штатов возможность выполнять роль посредника в этом процессе и ставят под сомнение возможность достичь «окончательной» договоренности между Израилем и палестинцами, а значит, и мира на этой многострадальной земле.

14. Режим доступа: http://edition.cnn.com/2016/12/17/politics/david-friedman-ambassador-to-israel-nomineel

15. Режим достуna: http://beforeitsnews.com/

16. CNN, February 16, 2017. 


\section{РОССИЯ И МИР В ХХІ ВЕКЕ}

\section{"От ворот поворот" на Восток}

В отличие от российской политики переориентации на евразийскую политику, которая была «разворотом», нацеленным на активизацию экономических отношений со странами, находящимися к востоку от России, американский «восточный поворот» был в первую очередь «разворотом против» Китая, имел в большей степени военную направленность против того, что в Вашингтоне представлялось как претензии Китая на доминирование в Азиатско-Тихоокеанском регионе.

Во время избирательной кампании Дональд Трамп неоднократно повторял, что Китай является главной угрозой для США, что эта страна заключала с США «самые грабительские сделки во всей истории США» и «нарушала все свои договоренности» ${ }^{17}$. Хотя затем он вынужден был сбавить тон конфронтационной риторики, а во время своей первой пресс-конференции сказал, что Соединенные Штаты будут иметь хорошие отношения и с Россией, и с Китаем.

Что касается военно-политических претензий Трампа к Китаю, то их можно суммировать следующим образом:

- Китай ведет агрессивную внешнюю политику по отношению к соседним странам, выдвигает в их адрес территориальные требования по поводу Парасельских островов и островов Спратли (на которые также претендуют Филиппины и Вьетнам);

- Китай стремится вытеснить США из региона;

- Китай ведет активную антиамериканскую деятельность в киберпространстве;

- Китай не оказывает должного давления на Северную Корею, не принуждает ее отказаться от своей ядерной программы.

«Китай вывозил из США огромные объемы денег и богатства за счет полностью односторонней торговли, но не хочет помочь с Северной Кореей / Дивно!» ${ }^{18},-$ писал Дональд Трамп в своем Твиттере. Выйдя из ТрансТихоокеанского партнерства (ТТП), Вашингтон, как указывалось на ситуационном анализе в ИНИОНе, продемонстрировал, что «если для администрации Обамы ТТП был одним из основных инструментов ограничения экономического и политического могущества Китая, то администрация Трампа, очевидно, в решении той же самой задачи будет делать ставку на жесткий протекционизм и военно-политические механизмы» [4].

17. Режим достyna: http://www.cnbc.com/2016/11/10/trumps-foreign-policy-heres-arecap-of-what-the-president-elect-said-about-asia-during-the-campaign.html? view=story\& $\% 24 D E V I C E \% 24=$ native-android-mobile

18. Режим достуna: https://twitter.com/realdonaldtrump/status/816068355555815424 148 
Американское руководство неоднократно обвиняло Китай в давлении на соседние страны, выражало недовольство по поводу китайских военных маневров, возмущалось возведением Китаем островов в Южно-Китайском море, что может превратить его во внутреннее море КНР - с ограничением доступа к американским военным базам. На слушаниях в комитете Сената по поводу его назначения на пост Государственного секретаря Рекс Тиллерсон говорил, что следует запретить Китаю возводить новые острова в Южно-Китайском море $^{19}$ и что американские Вооруженные силы воспрепятствуют этому.

В конце декабря 2016 г. Трамп высказал сомнения в отношении принципа «Одного Китая», на котором с 1979 г. базировалась американская политика в отношении этой страны и который заключается в официальном признании только пекинского правительства и признании Тайваня частью КНР (при наличии неофициальных отношений с Тайванем). Однако затем в первую декаду февраля 2017 г. во время телефонного разговора с китайским лидером Дональд Трамп подтвердил приверженность принципу «Одного Китая» и вновь подтвердил намерение развивать хорошие отношения с этой страной.

В Соединенных Штатах не могут не опасаться возможного сближения России и Китая и формирования между ними союза на антиамериканской основе. На эту тему неоднократно высказывались и американские эксперты, и представители общественно-политических кругов стран региона. В частности, профессор Университета Кейо Кэн Дзимбо, выступая в Московском Центре Карнеги, высказывал удивление, что этого до сих пор не произошло [6].

Очевидно, что Россия не будет рассматривать никаких возможностей «дружить против» Китая, считая его своим стратегическим партнером. И даже если в китайских документах подобная формулировка в отношении России отсутствует, взаимодействие с ближайшим соседом для Москвы слишком важно, чтобы ставить его в зависимость от перипетий российскоамериканских отношений.

\section{Кибервойны}

ими взаимодействие в борьбе против киберугроз?

Кибератаки в период избирательной кампании и перед инаугурацией нового президента стали главной темой американских внутриполитических дебатов. Если раньше в связи с киберугрозами в США в основном упоминался Китай, то в произошедших летом 2016 г. хакерских атаках на сервер нацио-

19. Sanger D.E., Flegenheimer M. In Rocky Hearing, Rex Tillerson Tries to Separate From Trump // New York Times. - 2017. - Jan. 11. 
нального комитета Демократической партии обвинили Россию. По мнению правительства Барака Обамы, российское правительство использовало хакерские группировки Fancy Bear и Cosy Bear для получения - в целях оказать влияние на политическую борьбу в США - компрометирующей информации. За 33 дня до инаугурации нового американского президента руководители ЦРУ, Национальной разведки и ФБР, встретившись и обсудив произошедшее, пришли к общему выводу относительно «масштаба, характера и намерения российского вмешательства». Американские спецслужбы согласились с тем, что таким образом российская сторона - хотя и без особых надежд на успех - стремилась помешать избирательной кампании Хиллари Клинтон. А также, возможно, пошатнуть американские структуры и подорвать престиж США за рубежом, вскрыв негативную сторону американской демократии.

А в январе - как раз перед обсуждением в Конгрессе хакерских атак Вашингтон накрыло девятым валом скандала, когда в СМИ просочилась непроверенная информация, будто бы несколькими годами ранее во время поездки Трампа в Москву, на него, с целью получения рычагов влияния, российскими спецслужбами было собрано компрометирующее досье.

Любопытно, что если раньше, по мнению российских специалистов, существовало расхождение в восприятии кибербезопасности между российской и американской стороной: в США говорили в основном о технических угрозах, а в России включали в понятие «кибербезопасности» и информационную, в том числе и пропагандистскую, составляющую (этот подход закреплен в новой российской Доктрине кибербезопасности), то теперь в американском «Докладе о российских хакерских атаках», представленном в Конгрессе, несколько страниц посвящены деятельности телеканала Russia Today. Теперь в Вашингтоне, как и в Москве, речь идет уже не только о «железе» и «софте», но и о «контенте».

Согласившись с тезисом о причастности Москвы к кибератакам, Дональд Трамп изменил свою первоначальную позицию - в течение долгого времени он отрицал российскую вину, выдвинутые обвинения называл «дурацкими» и саркастически адресовал призыв «к русским» вскрыть остальные 20 тыс. электронных сообщений Хиллари Клинтон, отправленных в нарушение служебных инструкций с ее персонального аккаунта. Однако после слушаний в Конгрессе, где был представлен "Доклад о российских хакерских атаках» и выдвинуты жесткие обвинения в адрес Москвы, Трамп распорядился провести в течение ближайших трех месяцев расследование хакерских атак, а спустя несколько дней согласился, что Москва стояла за ними.

В связи с обвинениями в адрес России правительство США - еще при Бараке Обаме - заявило, что ответит аналогично на хакерские атаки России. То есть, обвинив противоположную сторону в предосудительной практике, само объявило о намерении совершить подобное же преступление. Типичный 150 
пример порочного цикла «действие-противодействие», развивающейся по нарастающей гонки вооружений в киберпространстве. Однако представляется, что, осознав обострившееся в связи с американскими выборами внимание к проблеме, можно лучше понять связанные с ней угрозы и совместными усилиями осуществить меры по эффективному противодействию киберугрозами. Уместно вспомнить, что в свое время и Россия и Китай выступали за полный запрет кибероружия, а взаимодействие в борьбе с киберугрозами в течение длительного времени, даже после начала Украинского кризиса оставалось одной из немногих областей двустороннего российско-американского сотрудничества. В этом плане обсуждение совместных действий по борьбе с киберугрозами может и должно рассматриваться в рамках усилий по контролю над вооружениями, которое хоть и находится за рамками данного исследования, является абсолютно необходимым.

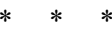

Американская внешняя политика меняется. В настоящее время существует масса неизвестных факторов, не дающих возможность однозначно прогнозировать дальнейшее развитие ситуации. С одной стороны, президент Трамп демонстрирует готовность в очень активном режиме выполнять многие предвыборные обещания. С другой стороны, продолжает делать часто противоречащие ранее сказанному заявления, иногда отвергая или смягчая самые крайние из декларировавшихся ранее тезисов или обнаруживая не озвученные ранее пути для компромиссов, в частности по Иранской сделке, отношениям с союзниками, взаимодействию с Китаем и др.

Очевидно, что надо использовать все возможности - как упущенные старые, так и открывающиеся новые - для восстановления нормальных отношений и их перехода из русла конфронтации на стезю сотрудничества. «Для России складывающаяся ситуация представляется перспективной, хотя и не безусловно выигрышной», - отмечалось на прошедшем в ИНИОН ситуационном анализе [4]. А председатель комитета по международным делам Совета Федерации Константин Косачев сказал: «У России в связи с этим должна быть повестка дня на американском направлении», назвав это «окном возможностей» [3].

Вместо «сдерживания» друг друга гораздо разумнее вместе сдерживать опасность двустороннего конфликта, международных и региональных кризисов. Но если исходить из реалистичных предпосылок, приходится констатировать, что элементы «сдерживания» в отношениях РФ и США будут и далее сохраняться. Важно, чтобы они были дополнены расширяющимся сотрудничеством по направлениям, где это возможно и необходимо, чтобы зоны взаимодействия увеличивались, конфронтация преодолевалась, а соперничество не 


\section{РОССИЯ И МИР В ХХІ ВЕКЕ}

переходило в новые конфликты. У России и США нет экзистенциальных противоречий. Но при наличии расходящихся интересов и представлений тем более настоятельна необходимость совместных действий по глобальным проблемам. При этом ограничение вооружений должно стать неотъемлемым компонентом российско-американских отношений при любом сценарии их развития и российской стороне следует проявлять инициативу по формировании повестки дня на данном направлении.

\section{Литература}

1. Безопасность и контроль над вооружениями 2015-2016. Международное взаимодействие в борьбе с глобальными угрозами / Отв. ред. А.Г. Арбатов, Н.И. Бубнова. - М.: ИМЭМО РАН, Политическая энциклопедия, 2016. - 303 с.

2. Бубнова Н.И. Военный фактор в политике Барака Обамы // Разоружение и безопасность 2013-2014. Стратегическая стабильность: Проблемы безопасности в условиях перестройки международных отношений. - М.: ИМЭМО РАН, 2014. - 245 с.

3. В Совете Федерации обсудили перспективы развития российско-американских отношений / Круглый стол «Российско-американские отношения при новой администрации Соединенных Штатов // Веб-сайт Совета Федерации РФ, 2017. 2 февраля. - http://www. council.gov.ru/events/news/76553/

4. Группа ситуационного анализа ИНИОН РАН обсудила первые шаги администрации Дональда Трампа. - ИНИОН РАН, 2017. - 31 января. - http://inion.ru/index.php?page_id= 208\&id=986\&ret $=\&$ printmode

5. Ефременко Д.В., Понамарева А.О. Трамп: Начало // Россия в глобальной политике. www.globalaffairs.ru/global-processes/Tramp-nachalo-18575

6. Стратегический прогноз глобального развития международных отношений, оборонной политики и экономики в Азиатско-Тихоокеанском регионе до 2030 года. - М.: Московский Центр Карнеги, 2013. - 7 июня. - http://carnegie.ru/2013/06/07/ru-event-4147

7. Cohen S. Who Is Making American Foreign Policy - The Accidental President or the War Party? // The Nation. - 2016. - September 21.

8. Confirmation Hearings, CNN, 2017. - January 12.

9. Knights M. Memo to Trump: Iraq Is Too Big to Fail // Foreign Policy. - 2017. - February 13.

10. Lorber E.B. President Trump and the Iran Nuclear Deal // Foreign Policy. - 2016. November. - http://foreignpolicy.com/2016/11/16/president-trump-and-the-iran-nuclear-deal/

11. Russia and Syria must face war crimes investigations, says John Kerry // Guardian. - 2016. October 7. - https://www.theguardian.com/us-news/2016/oct/07/syria-russia-war-crimes-inquiryjohn-kerry

12. Statement for the Record: Deputy Assistant Secretary Brett McGurk Senate Foreign Relations Committee Hearing: Iraq at a Crossroads: Options for U.S. Policy. - 2014. - July 24. http://www.foreign.senate.gov/imo/media/doc/McGurk\%20Testimony\%20072414-Final\%20Version $\%$ 20REVISED.pdf

13. Walt S.M. America's New President Is Not a Rational Actor // Foreign Policy. - 2017. January 25 . 